\title{
The Indonesian Macroeconomics Perspective: Halal Industry Sector be enhancing the Growth of Income per Capita
}

\author{
Dewi Mahrani Rangkuty ${ }^{1 *}$ \\ ${ }^{1}$ Economics Department, 20122 Universitas Pembangunan Panca Budi, Indonesia
}

\begin{abstract}
The purpose of writing this article is to examine the macroeconomic perspective of the halal industry sector on per capita income in Indonesia. The method used is qualitatively descriptive through the study of literature and literature. The halal industry sector in Indonesia has contributed to GDP based on the field sector. High GDP values support high per capita income through income distribution. There are several sub-sectors of the halal industry that contribute to the Indonesian economy. Recommended to the Indonesian government through the ministries of trade, MSMEs and Cooperatives to continue to support the acceleration of improvement in the realization of halal brands.
\end{abstract}

\section{Introduction}

The halal industry is often associated with an effort to produce a product (goods and services) by the provisions of Islam (Sharia). This definition has emerged recently due to the huge demand for halal products and services in the world. Previously, it was known that the halal industry was associated with the halal economy, where the mention of the halal economy was much earlier known than the halal industry (BI, 2020).

The halal industry is the latest trend in the world market. With the Muslim population reaching 3 billion people, the Halal industry becomes one of the fastest-growing businesses in the global market. It covers sectors such as finance, tourism, service, transportations, and food. Food is the essential thing in human life and the market potential for Halal food is very promising with Islam as the fastest-growing religion in the world (Ismali, 2015).

In its implementation, the halal industry, among others, has been regulated in Law No. 33 of 2014 on Halal Product Guarantee. The law aims to ensure the independence of each population to embrace their respective religions, where the state is obliged to provide protection and guarantees about the idolatry of the product. The law emphasizes that the products circulating in Indonesia are not only food and beverages, but also cosmetics, drugs, chemical products, biological products, engineering products, used goods, used, utilized by the community. In addition, this law also regulates halal services, including tourism, travel, media, and entertainment (BI, 2020).

\footnotetext{
* Corresponding author: dewimahrani@ dosen.pancabudi.ac.id
} 


\section{$A I \overline{I F B}$ Annual International Conference \\ on Islamic Economics and Business, 2021}

Indonesia is a country with a majority Muslim population. Indonesia is also known as a Muslim country. Indonesia is also one of the countries that popularize halal brands through halal products in the country. Including the term halal industry so that it contributes to the economy (Komalasari et al., 2020). Opportunities for the implementation of the halal industry can encourage the improvement of the Indonesian economy through various sectors of GDP business.

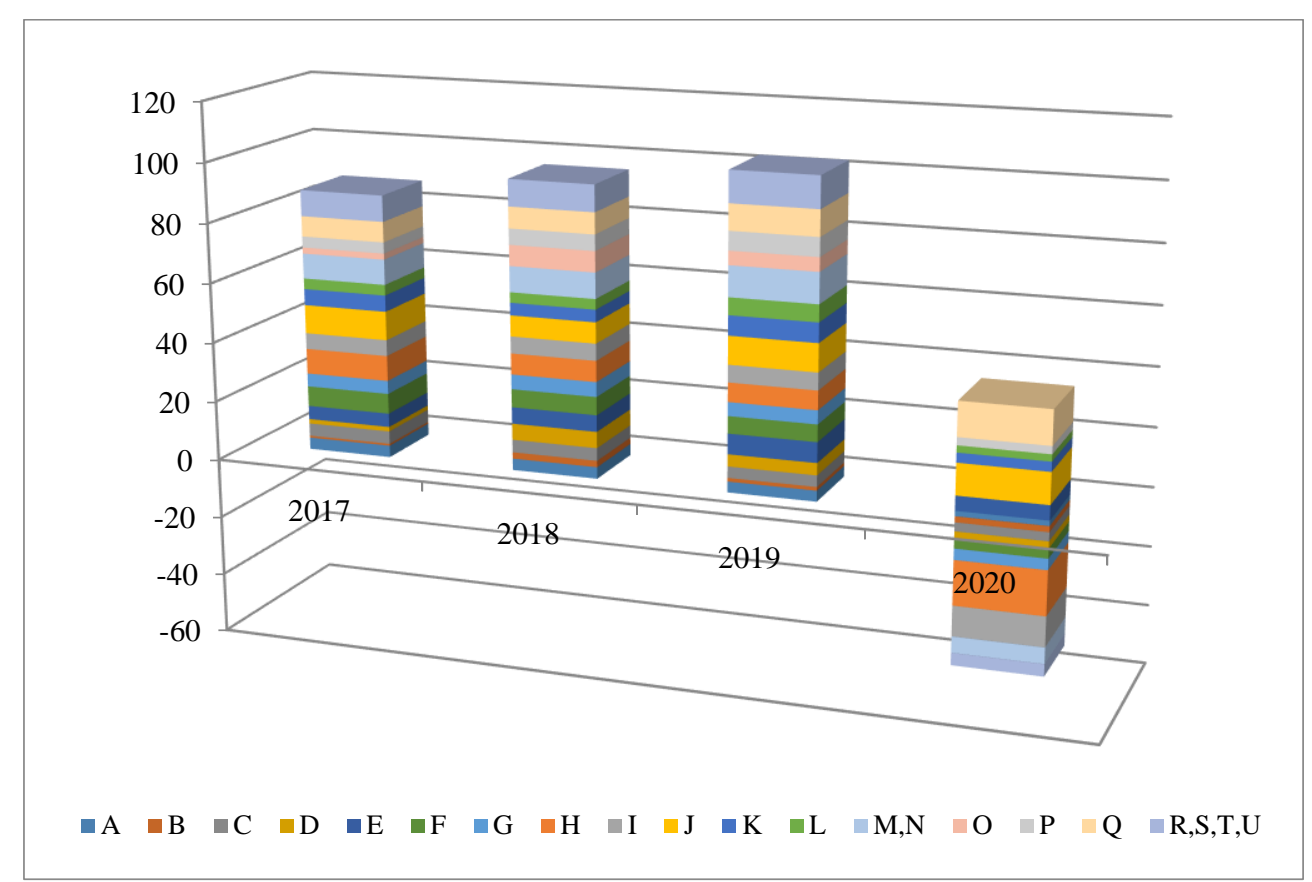

Source: (BPS, 2021)

Fig. 1. The Growth of Indonesian GDP by sector (\%), 2017-2020

Table 1. The Sector of GDP

\begin{tabular}{cl}
\hline A & Agriculture, Forestry, and Fishing \\
\hline B & Mining and Quarrying \\
\hline C & Manufacturing \\
\hline D & Electricity and Gas \\
\hline E & $\begin{array}{l}\text { Water Supply, Sewerage, Waste Management, and Remediation } \\
\text { Activities }\end{array}$ \\
\hline F & Construction \\
\hline G & Wholesale and Retail Trade, Repair of Motor Vehicles and \\
& Motorcycles \\
\hline H & Transportation and Storage \\
\hline I & Accomodation and Food Service Activities \\
\hline K & Information and Communication \\
\hline L & Financial and Insurance Activities \\
\hline M, N & Business Activities \\
\hline O & Public Administration and Defence, Compulsory Social Security \\
\hline P & Education \\
\hline Q & Human Health and Social Work Activities \\
\hline R, S, T, U & Other Services Activities \\
\hline
\end{tabular}




\section{$A \mathrm{IC} \quad$ Annual International Conference \\ on Islamic Economics and Business, 2021}

Based on Fig.1 and Table 1 shows Indonesia's GDP data based on the field sector of business. But from 17 business sectors provide opportunities for the application of halal industry or Sharia brands such as Manufacturing, Wholesale and Retail Trade, Food Service Activities, Financial and Insurance Activities, Business Activities.

Real national income or by fixed price is national income calculated at prices in a given year that is different from the year in which national production is calculated. Potential national income is the national income created when the economy reaches the level of full employment opportunities. While national income is the value of national products that are realized by economic activity in a given year (Sofyan, 2011).

Per capita income is the size of all income and all the population in a region or country. Per capita income is derived from the distribution of the national income of a country with the number of residents of the country in a certain period. Per capita income can be used to look at a country's level of well-being or standard of living from year to year. By doing such a comparison, we can observe whether the welfare of people in a country on average has improved. Rising per capita income is one sign that the average well-being of the population has increased. Per capita income also shows whether the progress of development that has been implemented by the government has been successful, how much success, and what consequences arise by the increase (Tristanto et al., 2013).

The contribution of the halal industry to the economy is shown in the increase in a country's per capita income. Industrial activities that refer to the real market (goods and services) also contribute to the distribution of income thus increasing a country's per capita income. Therefore, the purpose in the writing of this scientific article is to examine the macroeconomic perspective through the role of the halal industry to variable per capita income.

\section{Literature Review}

One component of national income that is always calculated is per capita income, which is the average income of a country's population at any given time. The value is obtained by dividing the value of Gross Domestic Product or Gross National Product of a given year by the number of residents in that year (Sukrino, 2016). The income per capita for as the macroeconomic perspective.

The halal industry has grown into a new manufacturing sector that is growing together into the fastest growing global business worldwide. This is in line with the increasing number of countries that accept the concept of halal as one of the determinants of the quality of a product (BI, 2020). The halal food industry sector in Indonesia has stronger potential in terms of production compared to people's incomes (Komalasari et al., 2020). The realization of the halal industry in countries in the world occurs in many sectors. The halal industry reflects on certification (Basir et al., 2020).

\section{Method}

The writing of this scientific article uses qualitative descriptive methods. Articles reviewing titles that define and describe phenomena through literature studies, collecting information and data from previous authors (Kurniawan, 2014).

So that in analyzing and reviewing macroeconomic perspectives related to the halal industry sector that increases per capita income in Indonesia through literature studies that provide an informational overview of several references to study and research results. 


\section{$A \mathrm{I} \overline{I E B}$ Annual International Conference \\ on Islamic Economics and Business, 2021}

\section{Discussion}

The global halal industry has shown significant development, and Indonesia has become one of the countries with great potential. This study aims to identify opportunities and challenges in developing the halal industry in Indonesia (Mubarok \& Imam, 2020). The development of the halal industry in Indonesia included several sectors, namely the food and beverage sector, tourism, fashion, media and recreation, pharmaceuticals and cosmetics, and renewable energy. In the future, to improve the halal industry in Indonesia, it is necessary to optimize the synergy of various elements ranging from the community, industry players, government, financial institutions, associations, academics, and educational institutions, as well as other related parties.

The potential for the Halal Industry is enormous, both for foreign and domestic needs in Indonesia. The need for commodities with halal guarantees for Muslim countries, even in non-Muslim majority countries, continues to increase from year to year, in the form of foodstuffs, medicines and cosmetics (Nugroho et al., 2020). The Halal Industry and Supply Chain from the scientific aspects of Industrial Engineering which include facts and data on the halal sector, regulations and sharia economics as a support for the halal industry, the halal food sector, halal operations, halal logistics (supply chain) and the potential of the halal industry in Indonesia.

The halal industry sector that supports economic movements increases economic growth in a region and/or country. Like Indonesia, the role of the halal industry sector has been realized in each province so as to support the gross domestic movement of gross regional that is seen in the following Fig.2.

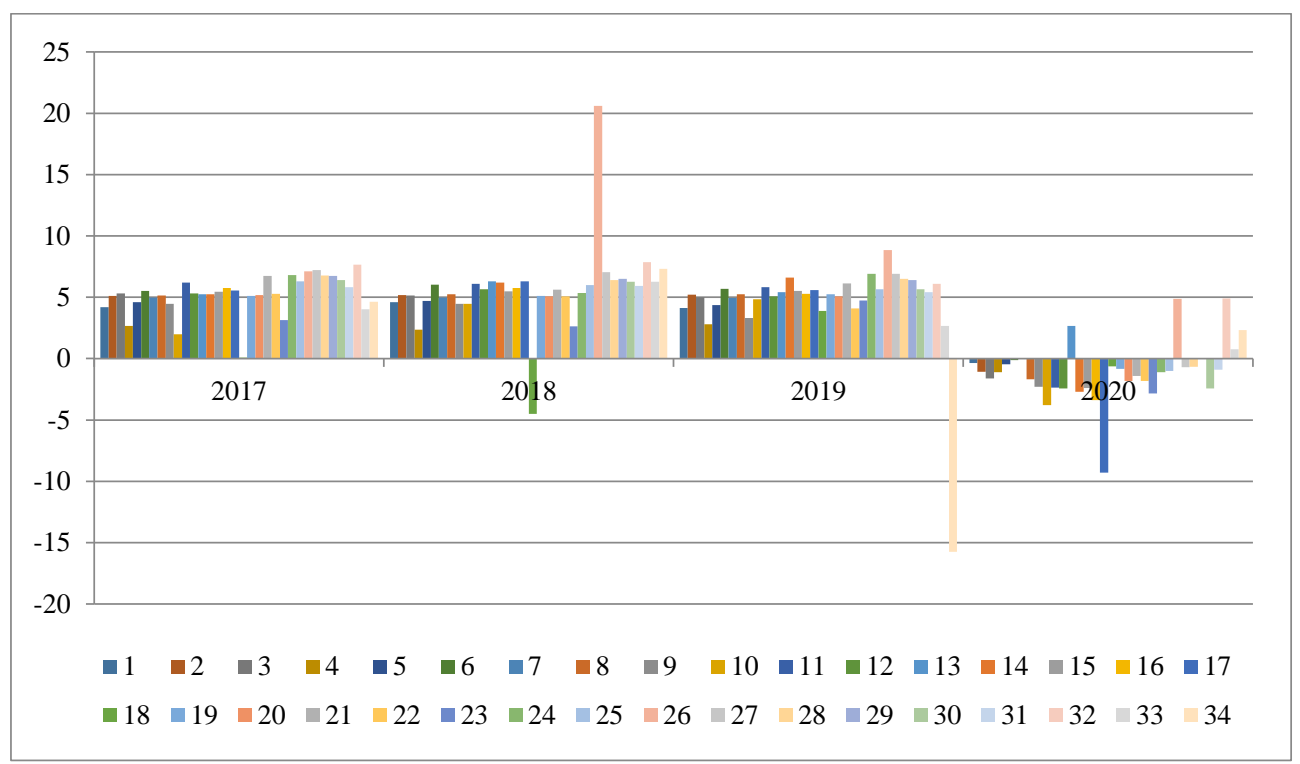

Source: (BPS, 2021)

Fig. 2. The Growth of Indonesian GDP by Province by the sector (\%), 2017-2020

Table 2. Indonesia's Province

\begin{tabular}{llcl}
\hline 1 & Aceh & 18 & Nusa Tenggara Barat \\
\hline 2 & Sumatera Utara & 19 & Nusa Tenggara Timur \\
\hline 3 & Sumatera Barat & 20 & Kalimantan Barat \\
\hline 4 & Riau & 21 & Kalimantan Tengah \\
\hline 5 & Jambi & 22 & kalimantan Selatan \\
\hline
\end{tabular}




\section{$A \bar{C} \quad$ Annual International Conference \\ on Islamic Economics and Business, 2021}

\begin{tabular}{clcl}
\hline 6 & Sumatera Selatan & 23 & Kalimantan Timur \\
\hline 7 & Bengkulu & 24 & Kalimantan Utara \\
\hline 8 & Lampung & 25 & Sulawesi Utara \\
\hline 9 & Kepulauan Bangka Belitung & 26 & Sulawesi Tengah \\
\hline 10 & Kepulauan Riau & 27 & Sulawesi Selatan \\
\hline 11 & DKI Jakarta & 28 & Sulawesi Tenggara \\
\hline 12 & Jawa Barat & 29 & Gorontalo \\
\hline 13 & Jawa Tengah & 30 & Sulawesi Barat \\
\hline 14 & DI Yogyakarta & 31 & Maluku \\
\hline 15 & Jawa Timur & 32 & Maluku Utara \\
\hline 16 & Banten & 33 & Papua Barat \\
\hline 17 & Bali & 34 & Papua \\
\hline
\end{tabular}

Based on Fig.2 and Table 2. That the Indonesian state when viewed by province then in every major island there are provinces with a majority Muslim population so that it has utilized the halal industry sector in the province. Both on the island of Sumatra, Java, Kalimantan, Sulawesi and Papua.

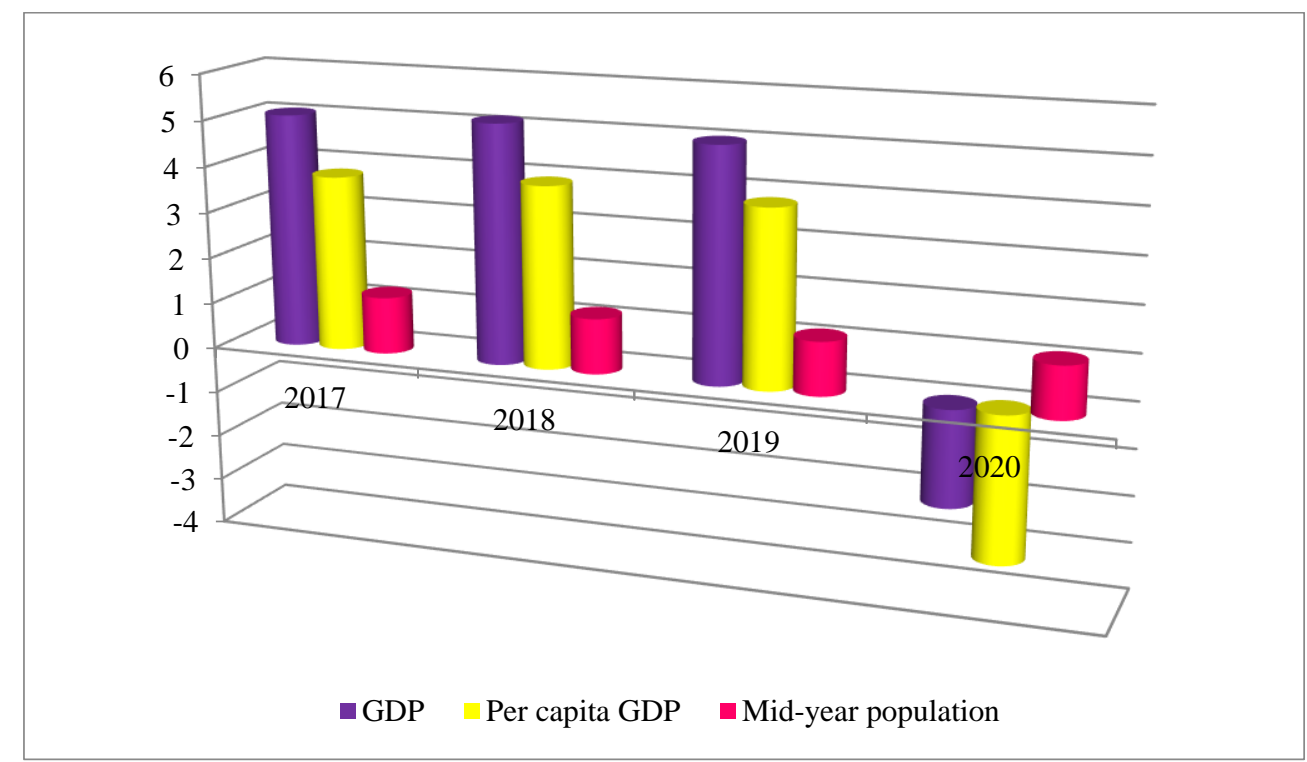

Source: (BPS, 2021)

Fig. 3. Indonesian GDP and Per capita GDP (\%), 2017-2020

The halal industry is a sector that's being developed globally. In Indonesia, the halal industry is a priority sector that is being developed by the government through the 2019 Sharia Finance National Committee (KNKS) master plan, the hope that this industry increase can encourage. Per capita income is the average of a country's income divided by the population. Both in the regional and national regions. The contribution of the halal industry sector that can increase regional and national income also encourages an increase in the value of per capita income.

Indonesia has a great opportunity in developing the world halal industry. This amount is the market share for products and services based on the halal industry sector. This is supported by the trend of increasing consumption of halal goods and services which is estimated to have 51 Halal Industrial Ecosystems of quite high growth. 


\section{Conclusion}

Macroeconomic perspective on the halal industry sector that the role and contribution of the halal industry sector to increase GDP will achieve the goal of increasing per capita income both regionally and nationally so that the presence of halal brands supports the acceleration of movement in Indonesia's economic activity. Recommended to the Indonesian government through the ministries of trade, MSMEs and Cooperatives to continue to support the acceleration of improvement in the realization of halal brands.

\section{References}

Basir, S. A., Othman, M. R., \& Munir, A. B. (2020). Nano product in Malaysia: A review of malaysia halal certification. Journal of Critical Reviews, 7(8). https://doi.org/10.31838/jcr.07.08.210

BI. (2020). Ekosistem Industri Halal. Dept. Ekonomi dan Keuangan Syariah-BI. https://www.bi.go.id/id/edukasi/Documents/EKOSISTEM HALAL 2020.pdf

BPS. (2021). Statistical Yearbook of Indonesia 2021 (Yearbook). BPS. https://www.bps.go.id/publication/2021/02/26/938316574c78772f27e9b477/statistikindonesia-2021.html

Ismali, R. M. (2015). Global Issues and Challenges for the Halal Food Industry. China (Ningxia) International Cooperation Forum on Halal Food Certification. https://doi.org/10.13140/RG.2.1.3096.5842

Komalasari, R., Nuryitmawan, T., Remi, S. S., \& Hadiyanto, F. (2020). How Does Halal Food On Your Plate Punch Indonesia's Economy? Jurnal Ekonomi Syariah Teori Dan Terapan, 7(12). https://doi.org/10.20473/vol7iss202012pp2385-2398

Kurniawan, A. (2014). Metode Riset untuk Ekonomi \& Bisnis.

Mubarok, F. K., \& Imam, M. K. (2020). Halal Industry in Indonesia; Challenges and Opportunities. Journal of Digital Marketing and Halal Industry, 2(1). https://doi.org/10.21580/jdmhi.2020.2.1.5856

Nugroho, I. S., Bhagya, T. G., \& Rosinawati, D. (2020). Industri dan Supply Chain Halal dilihat dari Aspek Keilmuan Teknik Industri. Sainteks: Jurnal Sains Dan Teknik, 2(2). https://doi.org/10.37577/sainteks.v2i2.264

Sofyan, M. (2011). Analisis Pengaruh Pendapatan Per Kapita, Tingkat Suku Bunga, Jumlah Uang Beredar (M2) dan Inflasi terhadap Jumlah Tabungan di Indonesia [UIN Syarif Hidayatullah]. https://repository.uinjkt.ac.id/dspace/bitstream/123456789/2851/1/MUHAMMAD SOFYAN-FEB.pdf

Sukrino, S. (2016). Teori Pengantar Makroekonomi. Rajawali Press.

Tristanto, Arisman, A., \& Fajriana. (2013). Pengaruh Jumlah Industri, PDRB dan Pendapatan Per Kapita Penerimaan Pajak Reklame sebagai Pendapatan Asli Daerah Kota Palembang. Jurnal Ekonomi. 